\title{
Assessment of accuracy of echocardiographic parameters in prenatal diagnostics of isolated vascular ring
}

\author{
Pavlova A. ${ }^{1}$, Gurjeva 0. ${ }^{1,3}$, Kurkevych A. ${ }^{1}$, Rudenko N. ${ }^{1,2}$, Yemec I. ${ }^{1}$ \\ ${ }^{1}$ Ukrainian Children's Cardiac Centre, Kiev \\ ${ }^{2}$ Shupyk National Medical Academy of Postgraduate Education, Kiev \\ ${ }^{3}$ The National Scientific Center «M.D. Strazhesko Institute of Cardiology» \\ of the Ukrainian National Academy of Medical Sciences
}

\begin{abstract}
Vascular ring (VR) is hard to diagnose prenatally and requires knowledge of anatomy of the large vessels, anatomical variants of VR and special echocardiographic views. In this study we aimed to find echocardiographic parameters which may predict diagnosis of VR.

From 2011 to 2017 diagnosis of the isolated VR was established prenatally and confirmed by computer tomography after birth in 39 cases (the main group). A control group comprised 47 fetuses with normal heart anatomy. The sizes of all heart structures in both groups were evaluated according to normograms corresponding to the pregnancy term and Z-scores were calculated.

Our study has shown, that in both study groups Z-score for majority of heart structures were in the normal range. Despite differences in Z-scores of mitral valve annular dimensions (MV), tricuspid valve and ductus arteriosus diameter were statistically significant, this difference was not clinically relevant and did not have predictive value for VR diagnostics. This finding was confirmed using non-parametric ROC-analyses. We may conclude that only routine use of special views is an effective method of prenatal ultrasound diagnostics of VR.
\end{abstract}

Key words: vascular ring, prenatal diagnosis, echocardiography.

Early prenatal ultrasound assessment for congenital malformation and in particular congenital heart disease (CHD) is a complex method which allows to organize specialized medical care in optimal terms before and after child's birth. $[8,12,13]$. The rates of prenatal diagnostics of the CHD remains low (from $30 \%$ to $70 \%$ ) even in developed countries [12]. Vascular rings (VR) are rare anomaly of the aortic arch, accounting for less than $1 \%$ of all CHD. Prenatal diagnosis of the VR is complex, requires knowledge of anatomy of the large vessels, anatomical variants of VR and special echocardiographic (Echo) views [5, 9-11]. We have focused on finding additional signs and diagnostic criteria that would assist in the diagnosis.

For the past decades RoC analysis has become a popular method for assessing the accuracy of medical diagnostic systems. The most important feature of it is that the accuracy criteria are not influenced by the decision criterion. The derived summary measure of accuracy, such as the area under the curve, determines the ability of the test to distinguish between the diseased and healthy in the study population. Use of this test of the diagnosis enables to evaluate diagnostic value of individual parameters or to assess whether a different combination of tests (for example, a combination of visualization methods) improve the accuracy of the diagnosis [6].

Objective. In this study we aimed to find echocardiographic parameters which may predict diagnosis of the isolated VR.
Materials and methods. In 2011 we have designed and implemented a new protocol of the fetal echocardiography with the views necessary for diagnostics of VR: 1) the 3 -vessel and trachea view, 2) the aortic arch long-axis view, 3 ) the transverse view of the upper abdomen to determine the position of the abdominal aorta.

From 2011 to 2017 the diagnosis of the isolated VR was established prenatally and confirmed after birth in 39 cases. They formed the main group 1. A control group 0 from 47 fetuses with normal anatomy of the heart and large vessels, confirmed postnatally, was formed.

Transabdominal fetal echocardiography and transthoracic echocardiography were performed on ultrasound scanners Philips Sonos 7500, Siemens Acuson Sequoia 512, Philips iU22, Philips iE33, Philips EPIQ 7 with the convection transducer with 9-1 MHz and sector transducers with $12 \mathrm{MHz}, 8$ $\mathrm{MHz}, 4-1 \mathrm{MHz}$ operating frequency. Computer tomography (CT) to confirm the ultrasound diagnosis of VR was performed on a 16-slice tomography Siemens Somatom Sensation.

Statistical data processing was carried out using SPSS software. Normality of distributions of continuous variables were studied using Shapiro-Wilk tests. Comparisons between the two study groups were conducted applying Mann-Whitney tests. ROC-analysis was applied for statistics which may had been hypothesized to have predicitive properties in detecting patients with VR. 
Results and discussion. In both groups, an estimation of the 4-chamber view, the views of the left and right ventricular tract, and the three vessels view were performed. All listed above views were normal in both groups.

In all fetuses left (LVED) and right (RVED) ventricles end-diastolic diameters, mitral (MV) and tricuspid (TV) valves diameters, the aortic valve diameter (AV), the ascending aortic diameter (AAOD), diameters of the valve (PV) and the main (MPA) pulmonary artery, diameter of the right branch of pulmonary artery (RPA), ductus arterio- sus (DA), diameter of the segment A of the aortic arch (seg. A), foramen ovale (FO) have been measured. The sizes of all heart structures were evaluated according to normograms according to the term of pregnancy and Z-score was calculated for each of them [1-3, 7]. In all fetuses, Z-score for all structures of the heart conformed to the norm (in the range from $-1,99$ to 1,99$)$.

Sizes of the MV $(-0,4 \pm 1$ to $-0,7 \pm 0,6 ; \mathrm{P}=0,049)$, TV $(-0,1 \pm 0,9$ to $-0,4 \pm 0,7 ; \mathrm{P}=0,044)$ were larger in VR group in comparison with the control group and the size of the

\section{Table 1}

Comparison of echocardiographic parameters in fetuses with (group 1) and without VR (group 0). Mann-Whitney test for independent samples

The Mann-Whitney test for independent samples

\begin{tabular}{|c|c|c|c|c|c|c|c|c|c|c|c|c|c|}
\hline \multirow[b]{3}{*}{ Indication } & \multicolumn{6}{|c|}{ Group $=0(n=47)$} & \multicolumn{6}{|c|}{ Group $=1(n=39)$} & \multirow[b]{3}{*}{$\mathbf{P}$} \\
\hline & \multirow[b]{2}{*}{ Mean } & \multirow[b]{2}{*}{ Median } & \multirow{2}{*}{$\begin{array}{l}\text { Standard } \\
\text { deviation }\end{array}$} & \multicolumn{3}{|c|}{ Percentiles (\%०) } & \multirow[b]{2}{*}{ Mean } & \multirow[b]{2}{*}{ Median } & \multirow{2}{*}{$\begin{array}{l}\text { Standard } \\
\text { deviation }\end{array}$} & \multicolumn{3}{|c|}{ Percentiles (\%०) } & \\
\hline & & & & 25 & 50 & 75 & & & & 25 & 50 & 75 & \\
\hline $\begin{array}{l}\text { Gestational age } \\
\text { (by BPD) }\end{array}$ & 24,2 & 22 & 5,5 & 20 & 22 & 30 & 24,5 & 24 & 4,3 & 21 & 24 & 28 & 0,536 \\
\hline BPD (sm) & 6,2 & 5,7 & 1,7 & 4,8 & 5,7 & 8,3 & 6,3 & 5,8 & 1,5 & 5 & 5,8 & 7,5 & 0,677 \\
\hline $\mathrm{HR}$ & 141,7 & 143 & 10,3 & 138 & 143 & 147 & 141,8 & 143 & 9,6 & 138 & 143 & 149 & 0,811 \\
\hline $\mathrm{FO}(\mathrm{mm})$ & 3,7 & 3,5 & 1,2 & 2,7 & 3,5 & 4,5 & 4,1 & 4 & 1,4 & 3,1 & 4 & 5 & 0,168 \\
\hline LVED (mm) & 8,8 & 7,8 & 2,8 & 6,6 & 7,8 & 11,3 & 9,2 & 8,7 & 2,7 & 6,8 & 8,7 & 11,4 & 0,344 \\
\hline Z-score for LVED & $-0,2$ & $-0,1$ & 0,7 & $-0,7$ & $-0,1$ & 0,3 & 0,01 & 0,1 & 0,9 & $-0,4$ & 0,1 & 0,5 & 0,269 \\
\hline RVED (mm) & 9,5 & 8,3 & 3,3 & 7,1 & 8,3 & 12,2 & 10,2 & 8,8 & 3,9 & 7,4 & 8,8 & 14 & 0,346 \\
\hline Z-score for RVED & 0,01 & 0,1 & 0,7 & $-0,3$ & 0,1 & 0,6 & 0,2 & 0,2 & 1,1 & $-0,3$ & 0,2 & 0,8 & 0,190 \\
\hline $\mathrm{MV}(\mathrm{mm})$ & 6,7 & 5,7 & 2,1 & 5,4 & 5,7 & 8,4 & 7,2 & 6,7 & 2,2 & 5,5 & 6,7 & 9 & 0,234 \\
\hline Z-score for MV & $-0,7$ & $-0,8$ & 0,6 & $-1,3$ & $-0,8$ & $-0,4$ & $-0,4$ & $-0,4$ & 1 & $-1,2$ & $-0,4$ & 0,4 & 0,049 \\
\hline $\mathrm{TV}(\mathrm{mm})$ & 7,2 & 6,1 & 2,5 & 5,6 & 6,1 & 9,2 & 8 & 6,7 & 3,1 & 5,5 & 6,7 & 10,2 & 0,306 \\
\hline Z-score for TV & $-0,4$ & $-0,4$ & 0,7 & $-0,9$ & $-0,4$ & $-0,2$ & $-0,1$ & $-0,1$ & 0,9 & $-0,8$ & $-0,1$ & 0,7 & 0,044 \\
\hline $\mathrm{AV}(\mathrm{mm})$ & 4,3 & 4 & 1,2 & 3,5 & 4 & 5,6 & 4,3 & 3,8 & 1,3 & 3,3 & 3,8 & 5,5 & 0,910 \\
\hline Z-score for AV & 0,8 & 0,9 & 0,8 & 0,5 & 0,9 & 1,3 & 0,6 & 0,7 & 0,8 & $-0,1$ & 0,7 & 1,1 & 0,168 \\
\hline AAOD $(\mathrm{mm})$ & 4,3 & 4 & 1,3 & 3,3 & 4 & 5,2 & 4,5 & 4 & 1,4 & 3,2 & 4 & 5,5 & 0,832 \\
\hline Z-score for AAOD & $-0,1$ & $-0,2$ & 0,9 & $-0,7$ & $-0,2$ & 0,5 & $-0,1$ & $-0,1$ & 0,7 & $-0,7$ & $-0,1$ & 0,4 & 0,990 \\
\hline $\mathrm{PV}(\mathrm{mm})$ & 5 & 4,4 & 1,8 & 3,7 & 4,4 & 6,5 & 5,3 & 4,9 & 1,8 & 4 & 4,9 & 6,4 & 0,364 \\
\hline Z-score for PV & 0,5 & 0,6 & 0,8 & 0,01 & 0,6 & 1,2 & 0,6 & 0,8 & 1,1 & 0,3 & 0,8 & 1,4 & 0,381 \\
\hline MPA (mm) & 5,2 & 4,4 & 2 & 3,8 & 4,4 & 6,5 & 5,5 & 5,1 & 2 & 4 & 5,1 & 6,5 & 0,306 \\
\hline Z-score for MPA & 0,1 & 0,1 & 0,7 & $-0,4$ & 0,1 & 0,7 & 0,3 & 0,3 & 0,9 & $-0,3$ & 0,3 & 0,7 & 0,294 \\
\hline $\mathrm{DA}(\mathrm{mm})$ & 3,5 & 2,9 & 1,4 & 2,6 & 2,9 & 4,3 & 3,3 & 3,1 & 1,1 & 2,4 & 3,1 & 4 & 0,543 \\
\hline Z-score for DA & 0,6 & 0,5 & 0,7 & 0,1 & 0,5 & 1 & 0,001 & $-0,1$ & 0,9 & $-0,8$ & $-0,1$ & 1 & 0,004 \\
\hline Seg. A (mm) & 3 & 2,7 & 1 & 2,4 & 2,7 & 3,7 & 3 & 2,6 & 1 & 2,2 & 2,6 & 3,3 & 0,587 \\
\hline Z-score for seg. A & $-0,1$ & $-0,1$ & 0,8 & $-0,7$ & $-0,1$ & 0,5 & $-0,5$ & $-0,4$ & 1 & $-1,2$ & $-0,4$ & 0,4 & 0,077 \\
\hline Seg. A/DA & 0,9 & 0,9 & 0,1 & 0,9 & 0,9 & 1 & 0,9 & 1 & 0,2 & 0,8 & 1 & 1,1 & 0,234 \\
\hline $\begin{array}{l}\text { Z-score for seg. } \\
\text { A/DA }\end{array}$ & $-0,7$ & $-0,5$ & 1 & $-1,1$ & $-0,5$ & $-0,2$ & $-0,5$ & $-0,2$ & 1,4 & $-1,5$ & $-0,2$ & 0,5 & 0,234 \\
\hline $\mathrm{RPA}(\mathrm{mm})$ & 2,2 & 2,1 & 1,4 & 1,6 & 2,1 & 3,2 & 2 & 2,1 & 1,5 & 0,01 & 2,1 & 3,5 & 0,756 \\
\hline Z-score for RPA & 0,1 & 0,01 & 0,6 & $-0,5$ & 0,01 & 0,4 & 0,1 & 0,01 & 0,6 & $-0,2$ & 0,01 & 0,6 & 0,503 \\
\hline $\begin{array}{l}\text { The term of } \\
\text { delivery }\end{array}$ & 39 & 40 & 2,4 & 39 & 40 & 40 & 38,6 & 39 & 2,2 & 38 & 39 & 40 & 0,073 \\
\hline Weight at birth & 3307,9 & 3300 & 502,7 & 3100 & 3300 & 3570 & 3117,6 & 3150 & 644,1 & 2820 & 3150 & 3585 & 0,215 \\
\hline Growth at birth & 51,5 & 51 & 3,4 & 50 & 51 & 53 & 51,3 & 52 & 3,8 & 50 & 52 & 53 & 0,457 \\
\hline
\end{tabular}




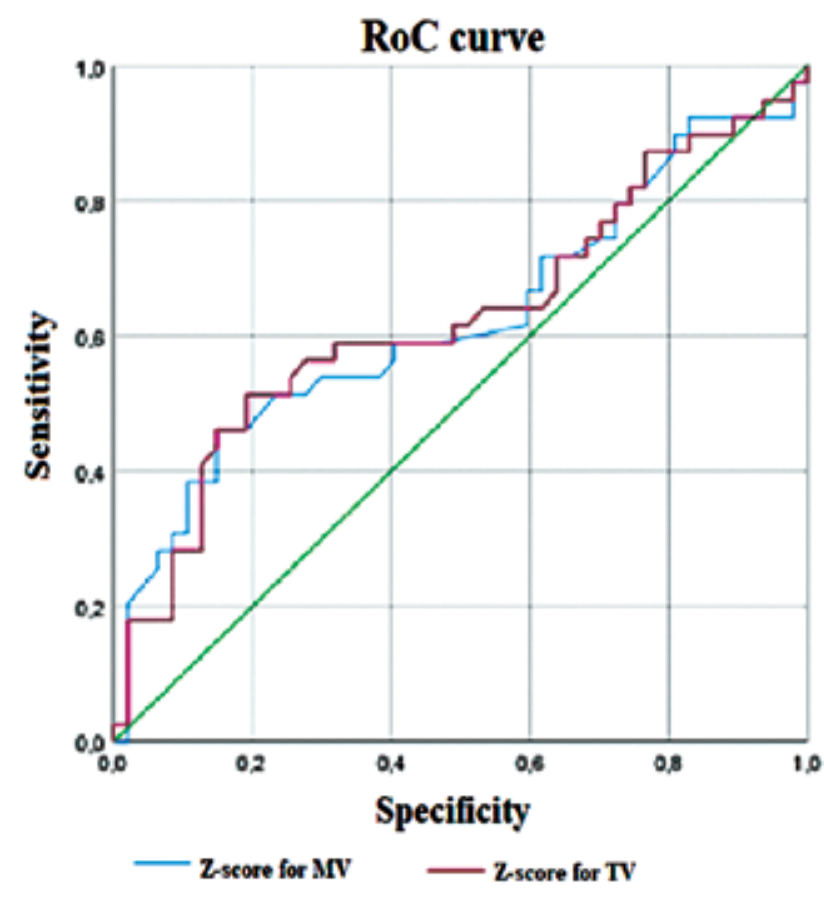

Fig.1. RoC-curve to Z-score for MV and TV

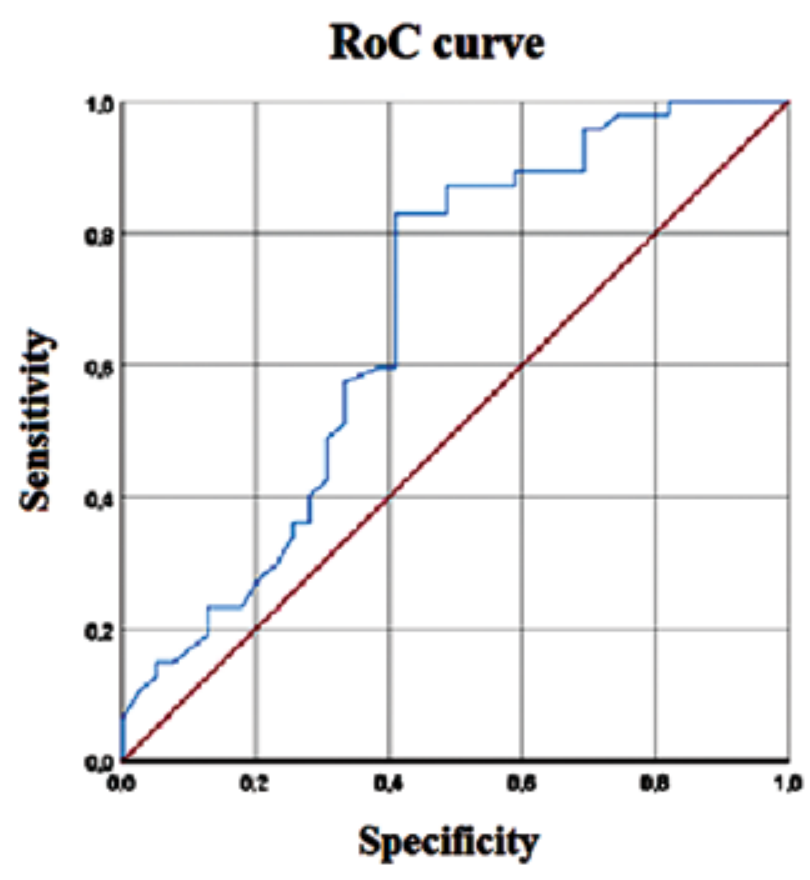

Fig.2. RoC-curve to Z-score for DA
DA $(0,6 \pm 0,7$ to $0,001 \pm 0,9 ; \mathrm{P}=0,002)$ were larger in control group in comparison with the VR group, but all parameters were within the normal range.

Despite significant difference between Z-scores of MV annular dimentios, of TV in study groups, the ROC-analysis shows that they are not diagnostic for VR. Nonparametric ROC-analysis revealed that area under the curve for $\mathrm{Z}$-score MV was $62,4 \%, P=0,049$. Area under the curve for TV was $62,7 \%, P=0,044$ which illustrates low sensitivity and specificity of this parameter in terms of VR diagnosis and does not meet diagnostic criteria.

When conducting a nonparametric ROC analysis $\mathrm{Z}$-score DA area under the curve is $67,9 \%, \mathrm{P}=0,004$; sensitivity and specificity is $<1,5 \%$ (Fig. 2 ).

Consequently, the only effective method of diagnosis of $\mathrm{SC}$ is the assessment of the anatomy and location of large vessels and trachea. To do this, it is necessary to use routine views for the diagnosis of VR: 1) the 3-vessel and trachea view (to evaluate the location of large vessels and trachea); 2) the aortic arch long-axis view (to assess the size of aortic arch and the presence of vascular pathology, including aberrant subclavian artery); 3) the transverse view of the upper abdomen to determine the position of the abdominal aorta.

Conclusions. The conclusion of the analysis is despite the significant difference between the Z-score MV, Z-score $\mathrm{TV}$ and $\mathrm{Z}$-score DA in both groups, the RoC curves show that they are not predictors of the diagnosis of VR. Only the routine use of special views is an effective method of prenatal ultrasound diagnostics of VR.

\section{References}

1. Comparison of cardiac Z-score with cardiac asymmetry for prenatal screening of congenital heart disease / T. Riggs, A. P. Saini, C. H. Comstock [et al.] // Ultrasound Obstet Gynecol. - 2011. - Vol. 38. - P. 332-6.

2. Development of $\mathrm{Z}$-scores for fetal cardiac dimensions from echocardiography / C. Schneider, B. W. McCrindle, J. S. Carvalho [et al.] // Ultrasound Obstet Gynecol. 2005. - Vol. 26. - P. 599-605.

3. Devore G. R. The use of Z-scores in the analysis of fetal cardiac dimensions // Ultrasound Obstet Gynecol. 2005. - Vol. 26. - P. 596-8.

4. Effect of prenatal diagnosis on hospital costs in complete transposition of the great arteries / D. Gupta, M. E. Mowitz, D. Lopez-Colon [et al.] // Prenat Diagn. - 2018. - Vol. 19.

5. Fetuses with right aortic arch: a multicenter cohort study and meta-analysis / F. D'Antonio, A. Khalil, V. Zidere [et al.] // Ultrasound Obstet Gynecol. - 2016. - Vol. 47. P. 423-32.

6. Receiver Operating Characteristic (ROC) Curve Analysis for Medical Diagnostic Test Evaluation / HajianTilaki K. // Caspian J Intern Med. - 2013. - Vol. 4. P. 627-35.

7. Predictive Models for Normal Fetal Cardiac Structures / A. Krishnan, J. I. Pike, R. McCarter [et al.] // J Am Soc Echocardiogr. - 2016. - Vol. 29. - P. 1197-1206.

8. Prenatal detection of congenital heart disease--results of a national screening programme / C. L. Van Velzen, S. A. Clur, M. E. Rijlaarsdam [et al.] // BJOG. - 2016. Vol. 123. - P. 400-7.

9. Prenatal diagnosis and outcome of right aortic arch without significant intracardiac anomaly / Y. Razon, M. Berant, 
R. Fogelman [et al.] // J Am Soc Echocardiogr. - 2014. Vol. 27. - P. 1352-8.

10. Prenatal diagnosis of vascular rings / S. Jain, B. Kleiner, A. Moon-Grady [et al.] // J Ultrasound Med. - 2010. Vol. 29. - P. 287-94.

11. Prenatal Sonographic Features of a Double Aortic Arch: Literature Review and Perinatal Management / D. Trobo, C. Bravo, T. Alvarez [et al.] // J. Ultrasound. Med. 2015. - Vol. 34. - P. 1921-7.
12. Systematic review and meta-analysis of the performance of second-trimester screening for prenatal detection of congenital heart defects / C. L. van Velzen, J. C .F. Ket, P. M. van de Ven [et al.] // Int J Gynaecol Obstet. - 2018. Vol. 140. - P. 137-145.

13. The impact of prenatal diagnosis on congenital anomaly outcomes: Data from 1997 to 2016 / P. Braz, A. Machado, C. Matias Dias [et al.] // Eur J Med Genet. - 2018. Vol. 14.

\title{
Проведення RoC-аналізу ехокардіографічних показників пренатально діагностованого ізольованого судинного кільця
}

\author{
Павлова А. О. ${ }^{1}$, Гур’єва О. С. ${ }^{1,3}$, Куркевич А. К. ${ }^{1}$, Руденко Н. М. ${ }^{1,2}$, ємець І. М. ${ }^{1}$. \\ ${ }^{1}$ ДУ «Науково-практичний медичний центр дитячої кардіології та кардіохірургії МОЗ України» (Київ) \\ ${ }^{2}$ Національна медична академія післядипломної освіти імені П. Л. Шупика (Київ) \\ ${ }^{3}$ Національний науковий центр «Інститут кардіології імені академіка М. Д. Стражеска НАМН України»
}

Рання ультразвукова пренатальна діагностика вроджених вад серця (ВВС) є складним методом, який дозволяє встановити діагноз до народження дитини та організувати спеціалізовану лікарську допомогу на високому рівні в оптимальні терміни [7, 11, 12]. Рівень пренатальної діагностики ВВС залишається низьким [11]. Пренатальна діагностика судинного кільця (СК) є складною, потребує знань анатомії великих судин, анатомічних варіантів СК і техніки спеціальних ЕхоКГ-проекцій [5, 8-10]. Пошук додаткових ознак і діагностичних критеріїв, які б допомогли в постановці даного діагнозу, став однією з частин дослідження, проведеного в нашому Центрі.

Метою даного дослідження було проведення RoC-аналізу для порівняння розмірів структур серця плода в нормі та за наявності ізольованого СК.

Матеріали та методи. 32011 р. в нашому Центрі при проведенні ЕхоКГ плода було впроваджено новий протокол з обов'язковими проекціями для діагностики СК. Всі обстеження проводились методом пренатальної трансабдомінальної та постнатальної трансторакальної ЕхоКГ на ультразвукових сканерах Philips Sonos 7500, Siemens Acuson Sequoia 512, Philips iU22, Philips iE33 Philips EPIQ 7 за допомогою конвексних датчиків частотою 9-1 МГц та фазованих секторних датчиків частотою 12 МГц, 8 МГц та 4-1 МГц. Для підтвердження ультразвукового діагнозу СК проводилась КТ на 16-зрізовому томографі Siemens Somatom Sensation. Статистична обробка даних проводилась у програмі SPSS.

Результати та обговорення. 32011 по 2017 pр. діагноз ізольованого СК було встановлено пренатально і підтверджено постнатально у 39 випадках, які склали основну групу 1. Контрольну групу 0 склали 47 плодів із нормальною анатомією серця. В обох групах усі основні ЕхоКГ-проекції відповідали нормі. В усіх плодів було виміряно кінцево-діастолічні розміри лівого та правого шлуночка, розміри мітрального та тристулкового клапанів, клапана аорти, висхідної Ао, клапана та стовбура легеневої артерії, правої гілки ЛА, артеріальної протоки, сегмента А дуги Ао. Розміри всіх структур серця були оцінені згідно з нормограмами відповідно до терміну вагітності та було розраховано Z-score до кожного з них [1-3, 6]. У всіх плодів Z-score розмірів всіх структур серця були в межах від -1,99 до 1,99, що відповідає нормі.

Розподіл показників вивчався з використанням тесту Шапіро-Уїлка. Оскільки показники не мали нормального розподілу, порівняння середніх величин не використовувалося. Застосовувався непараметричний аналіз - тест Манна-Уїтні та непараметричний аналіз ROC-кривих.

Відмічалась статистично достовірна різниця з переважанням розміру МK $(-0,4 \pm 1$ проти $-0,7 \pm 0,6 ; \mathrm{P}=0,049)$, розміру ТK $(-0,1 \pm 0,9$ проти $-0,4 \pm 0,7 ; \mathrm{P}=0,044)$ в основній групі та розміру АП $(0,6 \pm 0,7$ проти $0,001 \pm 0,9 ; \mathrm{P}=0,002)$ у контрольній групі.

При проведенні непараметричного ROC-аналізу Z-score MK площа під кривою становить 62,4\%, P=0,049, чутливість та специфічність складає $<1,5 \%$. При проведенні ROC-аналізy Z-score TK площа під кривою становить $62,7 \%, \mathrm{P}=0,044$. Чутливість та специфічність складає $<1,5 \%$. При проведенні непараметричного ROC-аналізу $\mathrm{Z}$-score артеріальної протоки площа під кривою становить $67,9 \%, \mathrm{P}=0,004$. Чутливість та специфічність складає $<1,5 \%$.

Висновки. Висновком проведеного аналізу є те, що, незважаючи на достовірну різницю показників Z-score MK, Z-score TK, та Z-score АП в обох групах, ROC-криві продемонстрували, що вони не є предикторами діагностики СК і лише рутинне використання спеціальних проекцій є ефективним методом пренатальної ультразвукової діагностики СК.

Ключові слові: судинне кільще, пренатальна діагностика, ехокардіографія. 